\title{
The influence of glutathion S-transferase $P$-1 polymorphism A313G rs1695 on the susceptibility to cyclophosphamide hematologic toxicity in Indonesian patients
}

\author{
Dita Hasni, ${ }^{1,2}$ Kamal B. Siregar, ${ }^{3}$ Hadyanto Lim ${ }^{1,4}$ \\ ${ }^{1}$ Biomedical Master Program, Faculty of Medicine, Universitas Sumatera Utara, Medan, Indonesia \\ 2 Departement of Pharmacotherapy, Faculty of Medicine, Universitas Baiturrahmah, Padang, Indonesia \\ ${ }^{3}$ Departement of Surgery, Faculty of Medicine, Universitas Sumatera Utara, Medan, Indonesia \\ ${ }^{4}$ Departement of Pharmacology, Faculty of Medicine, Universitas Methodist Indonesia, Medan, Indonesia
}

\section{ABSTRAK}

Latar belakang: Kemoterapisering menimbulkan efeksamping berupa toksisitas hematologi. Derajat toksisitas yang timbul sering dikaitkan dengan polimorfisme genetik. Penelitian ini bertujuan mengetahui apakah polimorfisme genetik GSTP1 A313G yang berperan pada detoksifikasi siklofosfamid dapat memprediksi insidensi dan derajat toksisitas hematologi siklofosfamid.

Metode: 91 perempuan Indonesia yang telah didiagnosis kanker payudara di RSUP Haji Adam Malik, Medan dan diterapi dengan regimen siklofosfamid, doxorubicin/epirubicin, dan 5-FU diikutsertakan pada penelitian kohort retrospektif ini. DNA diekstraksi dari leukosit perifer pasien dan dilanjutkan dengan pemeriksaan genotipe GSTP1 A313G dengan metode polymerase chain reaction-restriction length fragment polymorphism (PCR-RFLP). Distribusi frekuensi genotipe dan alel ditentukan dengan Hardy-Weinberg Equilibrium. Data derajat toksisitas hematologi (leukopenia dan neutropenia pasca-kemoterapi siklus 1 dan 3) dikumpulkan dari rekam medis pasien dan dianalisis dengan uji Kai kuadrat. Antar kelompok genotipe yang berbeda.

Hasil: Didapatkan proporsi GSTP1 A313A (wild type) 60,4\%, GSTP1 A313G (heterozigot mutan) 29,7\%, dan GSTP1 G313G (homozigot mutan) 9,9\%. Tidak ada penyimpangan frekuensi genotipe dan alel yang signifikan terhadap Hardy-Weinberg Equilibrium. Ditemukan pasien dengan alel $G(A / G \& G / G)$ cenderung mengalami leukopenia dengan derajat yang lebih berat dibandingkan dengan pasien GSTP1 wild type alel $(A / A)$ pasca-kemoterapi siklus ke-3 $(p<0,05)$.

Kesimpulan: Polimorfisme GSTP1 exon 5 A313G memiliki hubungan dengan derajat toksisitas hematologi pada pasien kanker payudara yang mendapat kemoterapi siklofosfamid.

\section{ABSTRACT}

Background: Chemotherapy often causes side effects such as hematologic toxicity. The degree of toxicity is often associated with genetic polymorphism. This study aims to determine the influence of GSTP1 A313G polymorphism, an enzyme responsible for detoxifying cyclophosphamid, on incidence and severity of cyclophosphamid hematologic toxicity.

Methods: 91 Indonesian females diagnosed with breast cancer at Haji Adam Malik Central General Hospital, Medan, receiving cyclophosphamide, doxorubicin/epirubicin and 5-FU were included in this retrospective cohort study. DNA was extracted from peripheral leukocytes and GSTP1 A313G genotyping was analyzed using polymerase chain reaction-restriction length fragment polymorphism (PCRRFLP). Genotype deviation and allele frequencies were also determined by Hardy-Weinberg Equilibrium. The degrees of hematologic toxicity (leucopenia and neutropenia data after chemotherapy cycles 1 and 3) were collected from the patient medical records. The data were analyzed using chisquare test.

Results: $60.4 \%$ of the patients had the wildtype (A/A), while $29.7 \%$ were heterozygous (A/G), and $9.9 \%$ were homozygous mutant $(G / G)$. There was no significant deviation of allele and genotype frequency from Hardy-Weinberg Equilibrium. The $G$ allele $(A / G \& G / G)$ contributes to more severe degree of leukopenia compared to patients with wild type allele $(\mathrm{A} / \mathrm{A})(\mathrm{p}<0.05)$ after the $3^{\text {rd }}$ chemotherapy cycles.

Conclusion: There was association between GSTP1 polymorphism with the degree of hematologic toxicity in breast cancer patients receiving cyclophosphamide chemotherapy regimen.

Keywords: breast cancer, cyclophosphamide, GSTP1 polymorphism, hematology toxicity

pISSN: 0853-1773 • eISSN: 2252-8083・ http://dx.doi.org/10.13181/mji.v25i2.1308・ Med J Indones. 2016;25:118-26

- Received 09 Nov $2015 \cdot$ Accepted 15 May 2016

Corresponding author: Dita Hasni, ditahasny@gmail.com

Copyright @ 2016 Authors. This is an open access article distributed under the terms of the Creative Commons Attribution-NonCommercial 4.0 International License (http://creativecommons.org/licenses/by-nc/4.0/), which permits unrestricted non-commercial use, distribution, and reproduction in any medium, provided the original author and source are properly cited. 
Cytotoxic chemotherapy is one of the modalities in breast cancer treatment, whether it is a neoadjuvant or adjuvant that aims to downstage, downsize and prevent metastasis to other organs. ${ }^{1}$ Cytotoxic chemotherapy, on the other hand, has side effects such as neutropenia and leucopenia, since the chemotherapeutic agents work indifferently on cancer cells and on normal cells which actively proliferate, such as blood cells. $^{2}$

Cyclophosphamide is one of the leading drugs for combination cytotoxic chemotherapy regimen in breast cancer treatment. Cyclophosphamide is a prodrug that requires phase I biotransformation for the activation of the cytotoxic active metabolite being mediated by CYP450 enzyme. Detoxification of cyclophosphamide requires phase II biotransformation mediated by glutathione S-tranferase 1 (GSTP1) enzyme by catalyzing the active metabolite with glutathione to form a non-toxic water soluble metabolite. ${ }^{3}$

GSTP1 is an important enzyme in detoxifying cyclophosphamide metabolites. This enzyme is expressed by GSTP1 gene which is located on the chromosome 11q13 and has non-synonymous nucleotide polymorphism at exon 5 at nucleotide 313 (SNP's ID:rs1695) where adenine changes to guanine. ${ }^{4}$ This causes the substitution of amino acid from isoleucine to valine at codon 105 which results in lower affinity between GSTP1 and its substrate up to $30 \%$ and affects the catalytic activity of GSTP1 during phase II biotransformation where the active metabolite is catalyzed to a non-toxic water soluble form. ${ }^{5}$ Zhang et $\mathrm{al}^{6}$ found that GSTP1 variant ${ }^{105} \mathrm{Val}$ has lower temperature stability which is influenced by catalytic activity of its substrates. Patients with homozygous isoleucine (Ile/Ile) have the highest GSTP1 enzyme activity and patients with heterozygous Ile/Val have a lower enzymatic activity compared to the homozygous mutant Val/Val. ${ }^{6} \mathrm{~A}$ study done by Zhong et $\mathrm{al}^{5}$ also found that GSTP1 activity in the erythrocyte was two to three times lower in GSTP1 Val/Val compared to Ile/Ile in various age groups. ${ }^{5}$

The polymorphism effect on GSTP1 enzymatic activity will have a downstream effect on activity of the cyclophosphamide detoxification process and its toxic metabolites (phosphoramide mustard and acrolein). This will accumulate toxic metabolites in the body which increases the risk of hematologic toxicity then severity in chemotherapy containing cyclophosphamide afterward. ${ }^{6,7}$ Tran et $\mathrm{al}^{8}$ reported that CYPB26, GSTA1, GSTP1 polymorphisms were related to incidence of severe hematologic toxicity in glomerulonephritis patients who receive cyclophosphamide therapy. ${ }^{8,9}$ Similar observations were also seen in studies done by Zhang et $\mathrm{al}^{6}$ and Artini et $\mathrm{al}^{10}$ which showed that breast cancer patients with GSTP1 Ile/Val and Val/Val polymorphisms has a tendency to experience the heavier degree of hematologic toxicity after chemotherapy compared to the wild type (Ile/Ile). ${ }^{6,10}$

To sum up the literature review, it is an urgency to downsize the number of drug-induced hematological toxicity especially leucopenia and neutropenia in our population from who were diagnosed breast cancer receiving cyclophosphamide, adriamycin/epirubicin and fluorouracyl regimens (CAF/CEF). This study conducted by aiming to determine the influence of genetic variance in the GSTP1 gene involved in detoxification of cyclophosphamide active metabolite could affect susceptibility on the incidence and severity of hematologic toxicity after cyclophosphamide chemotherapy.

\section{METHODS}

\section{Patient selection}

From July 2013 to February 2014, 91 Indonesian women were recruited in this retrospective cohort study. Subjects were selected from surgical oncology outpatient clinic of Adam Malik Hospital, Medan, Indonesia who fulfilled elligibility criteria in terms of a histopathological diagnosis as gold standard of breast cancer diagnosis which had been hospitalized and treated with a combination of cyclophosphamide, doxorubicin/epirubicin and 5-fluorouracyl (CAF/CEF). These regimens comprise $500 \mathrm{mg} / \mathrm{m}^{2}$ of cyclophosphamide, 50 $\mathrm{mg} / \mathrm{m}^{2}$ adriamicyn or $50 \mathrm{mg} / \mathrm{m}^{2}$ epirubicin, and $500 \mathrm{mg} / \mathrm{m}^{2} 5$-FU intravenously on day one of each 21 day-cycles, and repeated for a total of a minimum of three cycles of treatment. They had normal hematopoietic, liver, and renal functions prior to chemotherapy and excluded if they have received radiotherapy two months prior to chemotherapy, consumed enzyme inducers, 
and immunosuppressant less than two months prior to chemotherapy. Then, patients were recruited by consecutive sampling with inclusion and exclusion criteria set above. The protocol of this study was approved by Medical Faculty of Universitas Sumatera Utara Ethical Committee (No. 322/KOMET/FK USU/2013).

Demographic, clinico-pathological data and blood samples were collected from patient notes and medical record at medical oncology outpatient clinic where patients attended to treatment or follow-up regularly.

\section{Genomic DNA isolation}

After written informed consent was obtained from all participants, blood sample from each patient was collected into ethylenediaminetetraacetic acid (EDTA) containing storage tube and stored at $-20^{\circ} \mathrm{C}$ before deoxyribonucleic acid (DNA) extraction, then genomic DNA was purified from peripheral blood leucocyte using the Wizard ${ }^{\circledR}$ genomic DNA purification kit (Promega, USA) with procedure commonly used in integrated laboratory of Medical Faculty of Universitas Sumatera Utara

An amount of $1 \mathrm{~mL}$ of peripheral blood containing EDTA was transferred to Eppendorf tube and centrifuged in Eppendorf centrifuge 5,430 at speed of 3,000 RPM for 15 minutes at room temperature. The pellet-leucocyte form was pipetted as many as $300 \mu \mathrm{L}$ transferred to Eppendorf tube containing $900 \mu \mathrm{L}$ of red blood cell (RBC) lysis solution, then inverted three times and incubated at $3-5^{\circ} \mathrm{C}$ for 10 minutes. The sample was then centrifuged in centrifuge $5,702 \mathrm{R}$ at a speed of 13,000 RPM for three minutes at room temperature. The supernatant was removed by leaving the pellet in the form of mononuclear leucocytes.

The purification were repeated three times to obtain a white pellet, named as consideration the absence of red blood cells. Then the white pellet was added $300 \mu \mathrm{L}$ of nuclei lysis solution (NLS) and inverted until it became a homogenous solution. Next the solution added $100 \mu \mathrm{L}$ of protein precipitation solution and vortexed with an auto vortex (Biosan V-1 Plus) for 20 seconds. The lysate was centrifuged at 13,000 RPM for one minute at room temperature. Then, the supernatant was poured into a new Eppendorf contained $300 \mu \mathrm{L}$ isopropanolol. The tube was inverted 25 times until it formed a collection of DNA strands. Then the samples were centrifuged at 13,000 RPM for one minute at room temperature, so that DNAcontaining precipitate appeared white.

The supernatant was removed and then added $1 \mathrm{ml}$ of cold $70 \%$ ethanol, this mixture was then centrifuged at 13,000 RPM for one minute at room temperature. The supernatant was discarded and the DNA dried in open air by reversing the tube for one hour. DNA was rehydrated with $100 \mu \mathrm{L}$ DNA rehydration solution and then incubated at $4^{\circ} \mathrm{C}$ overnight. DNA yields were not estimated their concentration. Then they were stored at $-80^{\circ} \mathrm{C}$ until all of samples collected.

\section{Genotyping of GSTP1 single nucleotide polymorphism}

The amplification of isolated DNA was performed with polymerase chain reaction (PCR) with each reaction containing DNA GoTaq ${ }^{\circledR}$ Green Master Mix (Promega), the sequences of the forward and reverse primers for GSTP1 exon 5 were 5 '-GAG GAA ACT GAG ACC CAC TGAG-3' and 5'-AGC CCC TTT CTT TGT TCA GCC-3,'10,11 nuclease free water, and DNA template with the final volume of $25 \mu \mathrm{L}$. The DNA chain was denaturated by incubation at $94^{\circ} \mathrm{C}$ for five minutes, followed by 35 series of chain reaction $\left(94^{\circ} \mathrm{C}\right.$ for $30 \mathrm{~s}$, then annealed at $61^{\circ} \mathrm{C}$ for $30 \mathrm{~s}$, and $72^{\circ} \mathrm{C}$ for $30 \mathrm{~s}$ ) followed by final expansion step at $72^{\circ} \mathrm{C}$ for five minutes.

The PCR products were then visualized using $2 \%$ agarose gel electrophoresis stained with ethidium bromide and a DNA fragment at $424 \mathrm{bp}$ confirmed the amplification. The PCR products were then subjected to enzyme restriction with BsmA1 and incubated for 30 minutes at $55^{\circ} \mathrm{C}$ followed by visualization with $3 \%$ agarose gel electrophoresis stained with ethidium bromide. The wild type (A/A) allele showed fragments at 292 and $132 \mathrm{bp}$, the heterozygous allele $(A / G)$ showed fragments at $292,222,132$, and $70 \mathrm{bp}$ and the mutant (G/G) showed fragments at 222,132 , and $70 \mathrm{bp}$.

\section{DNA sequencing}

To validate data generated by polymerase chain reaction-restriction length fragment polymorphism (PCR-RFLP) assay, 10\% of the samples of unpurified PCR product were randomly sent to macrogen Inc and sequenced. The results of PCR product sequence were analyzed using basic local alignment search tool (BLAST ${ }^{\circledR}$ ). 


\section{Assessment of hematological toxicities}

The degree of hematological toxicity was evaluated from leukocyte and neutrophil count on day 19 after chemotherapy cycles one and three based on common terminology criteria for adverse events (CTCAE v.3.0). ${ }^{12}$

Degree of leucopenia (grade $\mathrm{I}=<4,000-3,000 /$ $\mathrm{mm}^{3}$, grade $\mathrm{II}=<3,000-2,000 / \mathrm{mm}^{3}$, grade $\mathrm{III}=<2,000-1,000 / \mathrm{mm}^{3}$, and grade $\mathrm{IV}=<1,000 /$ $\mathrm{mm}^{3}$ ). Degree of neutropenia (grade $\mathrm{I}=<2,500$ $1,500 / \mathrm{mm}^{3}$, grade $\mathrm{II}=<1,500-1,000 / \mathrm{mm}^{3}$, grade $\mathrm{III}=<1,000-500 / \mathrm{mm}^{3}$, grade $\mathrm{IV}=<500 / \mathrm{mm}^{3}$ ).

\section{Statistical analysis}

Qualitative variables were summarized by their frequency distribution and quantitative variables by their mean and standard deviation (SD) or median and interquartile range.

GSTP1 genotypes were tested as to whether they were distributed according to Hardy-Weinberg Equilibrium. Chi square test for deviation from Hardy Weinberg equilibrium was used to estimate differences in allele frequencies. The influence between GSTP1 genotype with cyclophosphamideinduced leucopenia and neutropenia after chemotherapy series one and three were estimated using $p$ value. A $p<0.05$ was considered statistically significant.

\section{RESULTS}

\section{Demography characteristics and subjects clinicopathology}

Total of 91 patients with the avarage age of $52.53 \pm 8.79$ years (range $30-76$ years) were evaluated in this study. The subjects consist of several ethnic groups consisting of 41 Bataknese patients (45.1\%), 30 Javanese patients (33.3\%), nine Acehnese patients (9.9\%), eight Malay (8.8\%), and the three rest patients (3.35\%) consists of Chinese, Dayaknese, and Indian ethnics. The clinico-pathological features of the subjects and variant genotype could be seen in Table 1 .

\section{DNA amplification to detect GSTP1 polymorphism}

Interpretation of RFLP product for the A313G on 424 bp PCR fragment with BsmA1 were shown by different pattern on gel electrophoresis (Figure 1). Digestion of the $424 \mathrm{bp}$ fragment of
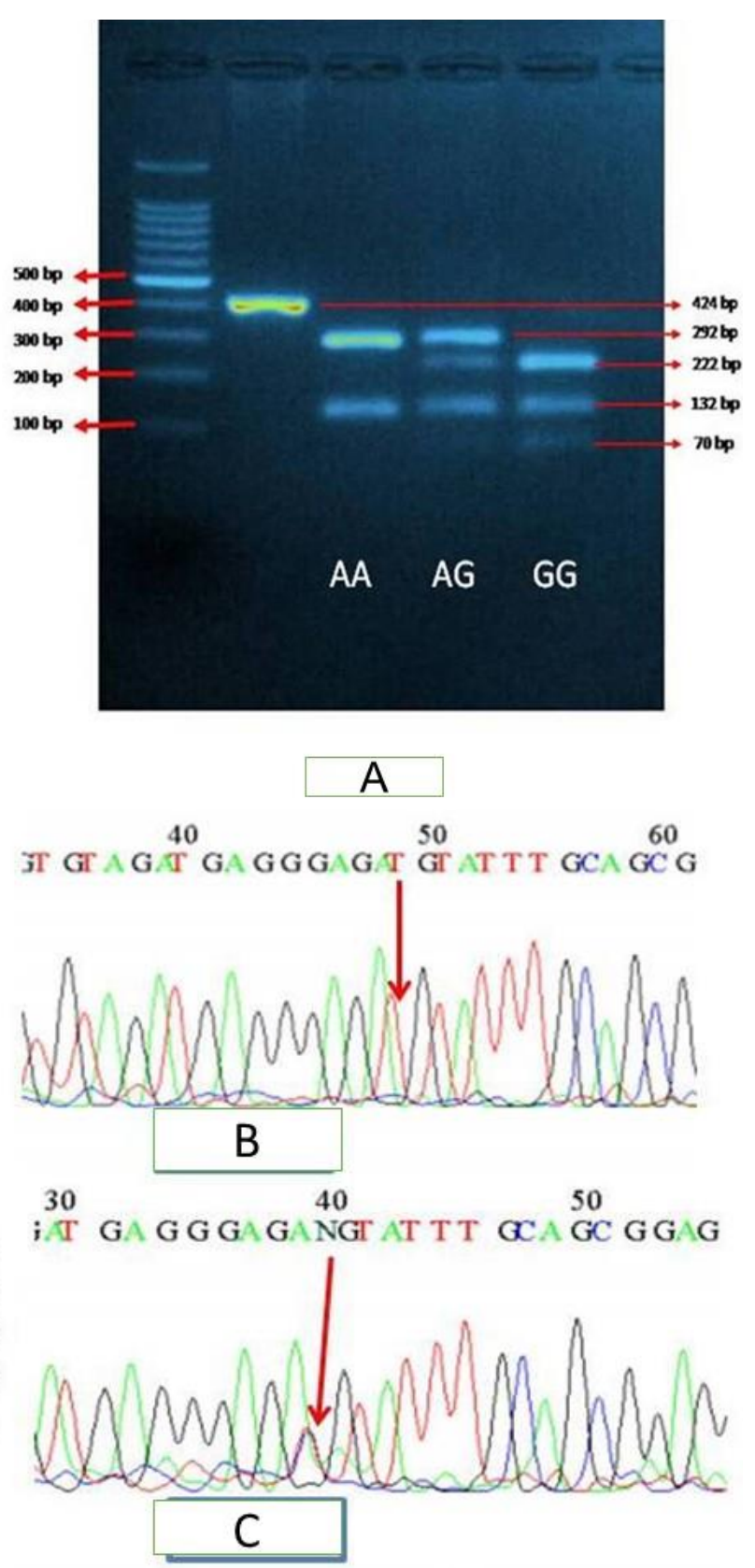

$40-50$
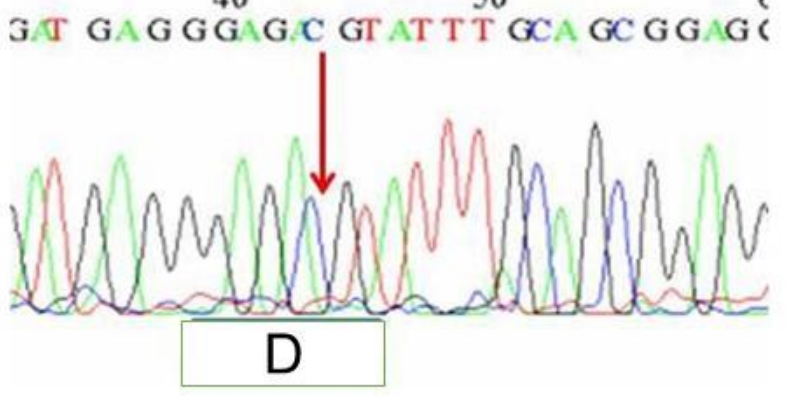

Figure 1. Genotyping result of GSTP1 A313G. Results of PCRRFLP analysis of glutathion S-transferase P1 polymorphism. GSTP1 exon 5 A313G was restricted by BsmA1 and resulted in 292 and 132 bp GSTP1 313AA fragments, 292, 222, 132, and $70 \mathrm{bp}$ GSTP1 313AG fragments and 222, 132, and $70 \mathrm{bp}$ GSTP1 313GG fragments. (A) electrophoresis of RFLP GSTP1 product; (B) sequences of GSTP1 313AA; (C) sequences of GSTP1 313 AG, (D) sequences of GSTP1 313 GG 
Table 1. Demographic and clinicopathological characteristics in various genotype subjects

\begin{tabular}{|c|c|c|c|c|}
\hline \multirow[b]{2}{*}{ Subject characteristics } & \multirow[b]{2}{*}{$\begin{array}{c}\text { All subjects } \\
n(\%)\end{array}$} & \multicolumn{3}{|c|}{ GSTP1 A313G genotype } \\
\hline & & $\begin{array}{c}\text { AA } \\
\text { n (\%) }\end{array}$ & $\begin{array}{c}\mathrm{AG} \\
\mathrm{n}(\%)\end{array}$ & $\begin{array}{c}\text { GG } \\
n(\%)\end{array}$ \\
\hline Total & 91 & 55 & 27 & 9 \\
\hline \multicolumn{5}{|l|}{ Ethnicity } \\
\hline Javanese & $30(33.0)$ & $19(63.3)$ & $10(33.3)$ & $1(3.3)$ \\
\hline Bataknese & $41(45.1)$ & $20(48.8)$ & $14(34.1)$ & $7(17.1)$ \\
\hline Malay & $8(8.8)$ & 7 (87.5) & 0 & $1(12.5)$ \\
\hline Acehnese & $9(9.9)$ & $6(66.7)$ & $3(33.3)$ & 0 \\
\hline The others & $3(3.3)$ & $3(100)$ & 0 & 0 \\
\hline Age (years, mean \pm SD) & $52.53 \pm 8.79$ & $53.16 \pm 8.57$ & $50.74 \pm 8.41$ & $54.00 \pm 11.28$ \\
\hline \multicolumn{5}{|l|}{ Breast cancer stage } \\
\hline IIa & $9(9.9)$ & $8(88.9)$ & $1(11.1)$ & 0 \\
\hline IIb & $23(25.3)$ & $14(60.9)$ & $7(30.4)$ & $2(8.7)$ \\
\hline IIIa & $7(7.7)$ & $1(14.3)$ & $4(57.1)$ & $2(28.6)$ \\
\hline IIIb & $47(51.6)$ & $28(59.6)$ & $14(29.8)$ & $5(10.6)$ \\
\hline IIIc & $4(4.4)$ & $3(75.0)$ & $1(25.0)$ & 0 \\
\hline IV & $1(1,1)$ & $1(100.0)$ & 0 & 0 \\
\hline \multicolumn{5}{|l|}{ Histopathology } \\
\hline Invasive ductal carcinoma & $77(84.6)$ & $49(63.6)$ & $20(26.6)$ & $8(10.4)$ \\
\hline Invasive lobular carcinoma & $12(13.2)$ & $5(41.7)$ & $7(58.3)$ & 0 \\
\hline The others & $2(2.2)$ & $1(50.0)$ & 0 & $1(50.0)$ \\
\hline \multicolumn{5}{|l|}{ Histopathological degree } \\
\hline Grade I & $22(24.2)$ & $12(54.5)$ & $10(45.5)$ & 0 \\
\hline Grade II & $34(37.4)$ & $22(64.7)$ & $6(17.6)$ & $6(17.6)$ \\
\hline Grade III & $21(23.1)$ & $12(57.1)$ & $8(38.1)$ & $1(4.8)$ \\
\hline Unknown & $14(15.4)$ & $9(64.3)$ & $3(21.4)$ & $2(14.3)$ \\
\hline \multicolumn{5}{|l|}{ Chemotherapy } \\
\hline Neoadjuvant & $57(62.6)$ & 34 (59.6) & $15(26.3)$ & $8(14.0)$ \\
\hline Adjuvant & $34(37.4)$ & $21(61.8)$ & $12(35.3)$ & $1(2.9)$ \\
\hline \multicolumn{5}{|l|}{ Chemotherapy regimen } \\
\hline $\mathrm{CAF}$ & $79(86.8)$ & $47(59.5)$ & $24(30.4)$ & $8(10.1)$ \\
\hline $\mathrm{CEF}$ & $12(13.2)$ & $8(66.7)$ & $3(25.0)$ & $1(8.3)$ \\
\hline
\end{tabular}

GSTP1= glutathion S-Transferase P-1; CAF= cyclophosphamide adriamycin fluorouracyl; CEF= cyclophosphamide epirubicin fluorouracyl

313 AA genotype gave two fragments of 292 and $132 \mathrm{bp}$, the 313 AG genotype resulted in four fragments at 292, 222, 132, and $70 \mathrm{bp}$, whereas the 313 GG genotype result in three fragments at 222,132 , and $70 \mathrm{bp}$. The PCR-RFLP results were confirmed with DNA sequencing.

\section{Distribution of GSTP1 polymorphism}

The genotype distribution of the patients is shown on Figure 2 which demonstrates that 55 patients $(60.4 \%)$ had the wild type $(\mathrm{A} / \mathrm{A})$, while 27 patients (29.7\%) were heterozygous (A/G), and nine patients
(9.9\%) were homozygous mutant (G/G). The allele frequencies of single nucleotide polymorphism (SNPs) A313G GSTP1 gene on this groups were $45(24.73 \%)$ of $\mathrm{G}$ allele, which is considered as minor allele frequency and 137 (75.27\%) of A allele classified as the major allele frequency.

In this study, we compared the distribution of GSTP1 genotype and allele frequency in various populations including Indonesian, South Korean, North Chinese, Taiwanese, Brazilian, Italian and tested for Hardy-Weinberg Equilibrium. The 
results are shown in Table 2 . The distribution of GSTP1 A313G genotypes in our data showed that it was not significantly deviated from HardyWeinberg equilibrium ( $p>0.05)$.

\section{Hematologic toxicity incidence}

The incidence of hematologic toxicity was evaluated from neutropenia and leucopenia after chemotherapy. The incidence of neutropenia in this study after cycle one chemotherapy was

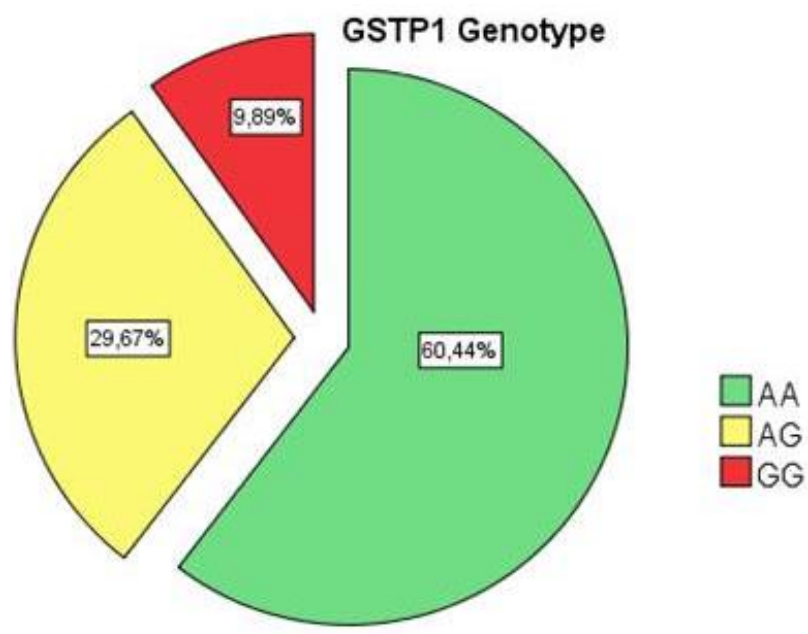

Figure 2. Distribution of genotype GSTP1 A313G polymorphism on subjects. The genotype distributions of the patients were as follows, $60.4 \%$ of the patient has the GSTP1 313AA (wild type), while $29.7 \%$ is GSTP1 313AG (heterozygous), and $9.9 \%$ is GSTP1 $313 \mathrm{GG}$ (homozygous mutant)
$38.5 \%$ and increased to $59.4 \%$ after chemotherapy cycle three. The incidence of leucopenia after the first cycle chemotherapy in this study was $12.1 \%$ and increased to $36.3 \%$ after the third cycle chemotherapy (Table 3).

\section{GSTP1 polymorphism and hematologic toxicity}

This study did not found difference in degree of neutropenia after CAF/CEF chemotherapy cycle one between the GSTP1 313AA and the GSTP1 $\mathrm{AG}+\mathrm{GG}$ genotypes, as well as post-chemotherapy cycle three.

Table 3. Degree of hematological toxicity after first and third cycles chemotherapy

\begin{tabular}{ccc}
\hline $\begin{array}{l}\text { Degree of hematological } \\
\text { toxicity }\end{array}$ & $\begin{array}{c}\text { After first cycle } \\
\mathrm{n}(\%)\end{array}$ & $\begin{array}{c}\text { After third cycle } \\
\mathrm{n}(\%)\end{array}$ \\
\hline Neutropenia & $35(38.5)$ & $54(59.4)$ \\
\hline Grade I & $22(24.2)$ & $28(30.8)$ \\
Grade II & $9(9.9)$ & $13(14.3)$ \\
\hline Grade III & $2(2.2)$ & $6(6.6)$ \\
Grade IV & $2(2.2)$ & $7(7.7)$ \\
\hline Leucopenia & $11(12,1)$ & $33(36.3)$ \\
\hline Grade I & $8(8.8)$ & $11(12.1)$ \\
\hline Grade II & $3(3.3)$ & $18(19.8)$ \\
Grade III & - & $3(3.3)$ \\
Grade IV & - & $1(1.1)$ \\
\hline
\end{tabular}

Table 2. Distribution of GSTP1 genotypes and allele frequency by Hardy-Weiberg Equilibrium on breast cancer patients in various population

\begin{tabular}{|c|c|c|c|c|c|c|c|}
\hline \multirow{2}{*}{ Population } & \multirow{2}{*}{$\begin{array}{c}\text { No of } \\
\text { individuals }\end{array}$} & \multicolumn{3}{|c|}{ GSTP1 Genotype [n, (\%)] } & \multicolumn{2}{|c|}{ Allele Frequency [n, (\%)] } & \multirow[b]{2}{*}{$\mathrm{p}$} \\
\hline & & AA & $\mathrm{AG}$ & GG & A & G & \\
\hline Medan, Indonesia (present study) & 91 & $55(60.4)$ & 27 (29.7) & $9(9.9)$ & $137(75.27)$ & $45(24.73)$ & 0.0529 \\
\hline Javanese & 30 & $19(63.3)$ & $10(33.3)$ & $1(3.3)$ & $48(80)$ & $12(20)$ & 0.8195 \\
\hline Bataknese & 41 & $20(48.8)$ & $14(34.1)$ & $7(17.1)$ & $54(65.85)$ & $28(34.15)$ & 0.1232 \\
\hline Malay & 8 & $7(87.5)$ & 0 & $1(12.5)$ & $14(87.5)$ & $2(12.5)$ & $0.0047^{*}$ \\
\hline Acehnese & 9 & $6(66.7)$ & $3(33.3)$ & 0 & $15(83.33)$ & $3(16.67)$ & 0.5485 \\
\hline The others & 3 & $3(100)$ & 0 & 0 & $6(100)$ & 0 & 0.6442 \\
\hline Yogyakarta, Indonesia $^{10}$ & 50 & $25(50)$ & $20(40)$ & $5(10)$ & $70(70)$ & $30(30)$ & 0.7363 \\
\hline Kazakhstan $^{16}$ & 120 & $63(52.1)$ & $46(38.7)$ & $11(9.2)$ & $172(71.67)$ & $68(28.33)$ & 0.5389 \\
\hline North China ${ }^{7}$ & 920 & $540(58.7)$ & $325(35.3)$ & $55(6.0)$ & $1405(76.36)$ & $435(23.64)$ & 0.5132 \\
\hline Taiwan $^{17}$ & 192 & $122(64.2)$ & $65(33.9)$ & $5(1.9)$ & 309 (80.89) & 73 (19.11) & 0.1637 \\
\hline Brazil & 750 & $330(44)$ & $329(44)$ & $91(12)$ & 989 (65.93) & $511(34.07)$ & 0.5198 \\
\hline Caucasian ${ }^{18}$ & 599 & $268(45)$ & $270(45)$ & $61(10)$ & $806(67.28)$ & $392(32.72)$ & 0.5608 \\
\hline African American & 151 & $62(41)$ & $59(39)$ & $30(20)$ & $183(60.6)$ & 119 (39.4) & $0.0255^{*}$ \\
\hline Italy $^{19}$ & 48 & $22(45.8)$ & $22(45.8)$ & $4(8.3)$ & $66(68.75)$ & $30(31.25)$ & 0.6442 \\
\hline
\end{tabular}

* Significant; GSTP1= glutathion S-transferase P-1 
This study reported did not found difference in degree ofleucopenia after CAF/CEF chemotherapy cycle one between the GSTP1 313AA and the GSTP1 313AG+GG genotypes but a significant difference in degree of leucopenia was found after cycles three chemotherapy $(\mathrm{p}<0.05)$ (Table 4 and Table 5).

\section{DISCUSSION}

Cyclophosphamide is a cytotoxic agent used for breast cancer treatment which can suppress

Table 4. Degree of hematological toxicity after first cycle chemotherapy in GSTP1 genotype

\begin{tabular}{lccc}
\hline $\begin{array}{l}\text { Hematological toxicity, } \\
\text { genotype }\end{array}$ & $\begin{array}{c}\text { Grade } 1-2 \\
\mathrm{n}(\%)\end{array}$ & $\begin{array}{c}\text { Grade } 3-4 \\
\mathrm{n}(\%)\end{array}$ & $\mathrm{p}$ \\
\hline $\begin{array}{l}\text { Neutropenia } \\
\text { AA }\end{array}$ & $\begin{array}{c}31 \\
\text { (70.96) }\end{array}$ & $4(100)$ & $0.546^{*}$ \\
AG & $8(25.81)$ & $0(0)$ & \\
GG & $1(3.23)$ & $0(0)$ & \\
\hline AG and GG & $9(29.04)$ & $0(0)$ & $0.286^{+}$ \\
Leucopenia & 11 & 0 & N/A \\
\hline AA & $9(81.82)$ & 0 & \\
AG & $1(9.09)$ & 0 & \\
GG & $1(9.09)$ & 0 & \\
AG and GG & $2(18.18)$ & 0 & N/A \\
\hline
\end{tabular}

* Kolmogorov-Smirnov; † Fisher exact test; GSTP1= glutathion S-transferase P-1; N/A= statistical test not applicable; $\mathrm{AA}=$ adenine adenine; $\mathrm{GG}=$ guanine guanine; $\mathrm{AG}=$ adenine guanine

Table 5. Degree of hematological toxicity after third cycle chemotherapy in GSTP1 genotype

\begin{tabular}{|c|c|c|c|}
\hline $\begin{array}{l}\text { Hematological toxicity, } \\
\text { genotype }\end{array}$ & $\begin{array}{l}\text { Grade I-II } \\
\text { n (\%) }\end{array}$ & $\begin{array}{c}\text { Grade III-IV } \\
\text { n (\%) }\end{array}$ & $\mathrm{p}$ \\
\hline Neutropenia & 41 & 13 & $0.772^{*}$ \\
\hline $\mathrm{AA}$ & $29(70.73)$ & $6(46.15)$ & \\
\hline $\mathrm{AG}$ & 8 (19.51) & $6(46.15)$ & \\
\hline GG & $4(9.76)$ & $1(7.69)$ & \\
\hline $\mathrm{AG}$ and $\mathrm{GG}$ & $12(29.27)$ & 7 (53.85) & $0.106^{\dagger}$ \\
\hline Leucopenia & 29 & 4 & $0.035^{\mathrm{a}}$ \\
\hline $\mathrm{AA}$ & $22(75.86)$ & 0 & \\
\hline$A G$ & $6(20.69)$ & $3(75.0)$ & \\
\hline GG & $1(3.45)$ & $1(25.0)$ & \\
\hline $\mathrm{AG}$ and $\mathrm{GG}$ & $7(63.6)$ & $4(100)$ & 0.004 \\
\hline
\end{tabular}

* Kolmogorov-Smirnov test; $\uparrow$ pearson chi square test; $\$$ fisher exact test; GSTP1= glutathion S-transferase P-1 cancer and normal cell such as blood cells since these cells are actively proliferating. ${ }^{2}$ Blood cells with the shortest life span will firstly experience suppression and followed by other cells with the order of neutrophils, leucocytes, platelets and erythrocytes. ${ }^{2,13}$

In this study, $38.5 \%$ and $59.4 \%$ of breast cancer patients suffered neutropenia after first and third cycles of CAF/CEF chemotherapy respectively. Previous study by Han et al ${ }^{14}$ also showed similar results. In early stage breast cancer, $52.5 \%$ patients who received CEF adjuvant chemotherapy experienced neutropenia with mild neutropenia (degree one and two) of $41.5 \%$ and severe degree (degree three and four) of $11 \% .^{14}$

The incidence of neutropenia after first cycle chemotherapy in this study is higher than previous study done by Keswara et $\mathrm{al}^{13}$ which shows the incidence of neutropenia $27.4 \%$ after 12 days of cycle one CAF chemotherapy. ${ }^{13}$ his difference might be due to difference in time of observation. In this study, neutropenia occurred on day 19 whilst in the study of Keswara et al ${ }^{13}$ it took place on days seven and 12 .

In this study, $11.1 \%$ and $36.3 \%$ of breast cancer patients suffered from leucopenia after first and third cycles CAF/CEF chemotherapy, respectively. The results after third cycle chemotherapy closely resemble previous study by Artini et al ${ }^{10}$ which showed $38 \%$ of breast cancer patients receiving cyclophosphamide in taxan-based and antracyclin-based regimens, experienced leucopenia after treated overall cycles of chemotherapy. ${ }^{10}$ The incidence of leucopenia in this study, however, was much lower than the study done by Palappallil et $\mathrm{al}^{15}$ in breast cancer patients receiving CAF regimen. These authors reported that $66 \%$ and majority of the subject only showed degree one leucopenia. ${ }^{15}$ The difference in incidence of leucopenia between this study and study of Palappallil et $\mathrm{al}^{15}$ may be attributed to difference in observation times: cycles one and three in this study vs all cycles in this study.

In this study, genotype counts did not significantly deviate from those expected from the HardyWeinberg equilibrium $(\mathrm{p}=0.053)$. This finding is similar to the Yogyakarta, Indonesian, ${ }^{10}$ Khazakstan, ${ }^{16}$ Chinese, ${ }^{7}$ Taiwanese, ${ }^{17}$ Brazilian, ${ }^{18}$ and Italian. ${ }^{19}$ But in Malay subjects from our 
data showed a significant deviated from HardyWeinberg equilibrium. This result is similar to African American race from Brazilian population. ${ }^{18}$

The present study investigates the influence of GSTP1 polymorphism on susceptibility of hematological toxicity induced by cyclophosphamide. Our results showed there was no difference in degree of leucopenia between GSTP1 genotypes after chemotherapy cycle one, which is in contrast with that after cycle three of chemotherapy. GSTP1 313AG+313GG genotype had higher incidence of three to four degree leucopenia than GSTP1 313AA genotype $(p=0.035$ and $p=0.004$ ). This may be due to the accumulation of cycloposphamide and its metabolites due to decreased activity of detoxifying enzymes GSTP1 for the GSTP1 313AG+GG genotype.

Our results also found that after cycles one and three chemotherapy, there were no differences in the degree of neutropenia between the GSTP1 313AA and The GSTP1 313AG+GG genotypes. The situation is different with the incidence of leukopenia, probably due to the shorter life cycle of neutrophil than that of leukocytes. So at day 19 post chemotherapy blood neutrophil levels have returned to normal

Therefore, it is concluded that there is an association between GSTP1 polymorphism and hematological toxicity induced by cyclophosphamide. This finding is similar to previous study which showed higher incidence of severe hematologic toxicity in GSTP1 313AG+GG patients compared to GSTP1 313AA. This is in contrast to the findings of Ekhart et $\mathrm{al}^{9}$ which stated that GSTP1 polymorphism had no influence on inter-individual cyclophosphamide and 4-hydroxycyclophosphamide pharmacokinetics. ${ }^{9}$ Ekhart et $\mathrm{al}^{20}$ stated that GSTP1 polymorphism cannot be the contributing factor to variations of toxicological response.

In conclusion, our data indicated that host constitutional variability such as GSTP1 polymorphism played a role in the severity of hematologic toxicity in patients receiving cyclophosphamide in CAF/CEF regimen. It will be interesting to determine the polymorphism of metabolic enzymes involved in phase I and phase II biotransformation, especially drugs involved in the chemotherapy regimens. By this way, individual analysis can be done to anticipate side effects of chemotherapy, especially hematologic toxicity.

\section{Conflicts of interest}

The authors affirm no conflict of interest in this study

\section{Acknowledgment}

The authors highly appreciate the support from Head of Surgical Oncology Department of Adam Malik Hospital, Medan, dr. Emir Taris Pasaribu, SpB(K)Onk; Head of Basic Medical Science Postgraduate Program, Faculty of Medicine Universitas Sumatera Utara, dr. Yah Wardiyah Siregar, $\mathrm{PhD}$, and the support from dr. Datten Bangun, Msc, SpFK, Mardiah Nasution, Indra Wahyudi, and Donny Nauphar.

\section{REFERENCES}

1. Thirumaran R, Prendergast GC, Gilman PB. Cytotoxic chemotherapy in clinical treatment of cancer. In: Prendergast GC, Jaffee EM, editors. Cancer immunotherapy: immune suppresion and tumor growth. USA: Elsevier Inc; 2007. p. 101-16.

2. Daniel D, Crawford J. Myelotoxicity from chemotherapy. Semin Oncol. 2006 Nov;33(1):74-85.

3. Zhang J, Tian Q, Zhou SF. Clinical pharmacology of cyclophosphamide and ifosfamide. Curr Drug Ther. 2006 Jan;1(1):55-84.

4. Tew KD, Manevich Y, Grek C, Xiong Y, Uys J, Townsend DM. The role of glutatione S-Transferase P in signalling pathways and S-glutathionylation in cancer. Free Radic Biol Med. 2011 July;51(2):299-313.

5. Zhong SL, Zhou SF, Chen X, Chan SY, Chan E, Ng KY, et al. Relationship between genotype and enzyme activity of glutathione S-transferases M1 and P1 in Chinese. Eur J Pharm Sci. 2006 Jan;28(1-2):77-85.

6. Zhang BL, Sun T, Zhang BN, Zheng S, Lü N, Xu BH, et al. Polymorphisms of GSTP1 is associated with differences of chemotherapy response and toxicity in breast cancer. Chin Med J. 2011 June;124(2):199-204.

7. Ge J, Tian A, Wang QS, Kong PZ, Yu Y, Li XQ, et al. The GSTP1 105Val allele increases breast cancer risk and aggressiveness but enhances response to cyclophosphamide chemotherapy in North China. PLoS One. 2013 June;8(6):e67589.

8. Tran A, Bournerias F, Le Beller C, Mir O, Rey E, Pons G, et al. Serious haematological toxicity of cyclophosphamide in relation to CYP2B6, GSTA1 and GSTP1 polymorphisms. Br J Clin Pharmacol. 2008 Sep;65(2):279-80.

9. Ekhart C, Doodeman VD, Rodenhuis S, Smits PH, Beijnen JH, Huitema AD. Influence of polymorphisms of drug metabolizing enzymes (CYP2B6, CYP2C9, CYP2C19, CYP3A4, CYP3A5, GSTA1, GSTP1, ALDH1A1 and ALDH3A1) on the pharmacokinetics of 
cyclophosphamide and 4-hydroxycyclophosphamide. Pharmacogenet Genomics. 2008 Feb;18(6):515-23.

10. Artini IGA, Astuti I, Purwono S, Aryandono T. The association between glutathione S-Transferase P1 polymorphism and myelotoxicity in breast cancer patients receiving cyclophosphamide-contained chemotherapeutic regimen. Indones J Cancer. 2011 Sep;5(4):1-7.

11. Zhong S, Huang M, Yang X, Liang L, Wang Y, Romkes M, et al. Relationship of glutathione S-transferase genotypes with side-effects of pulsed cyclophosphamide therapy in patients with systemic lupus erythematosus. Br J Clin Pharmacol. 2006 July;62(4):457-72.

12. ctep.cancer.gov [Internet]. Cancer therapy evaluation program: common terminology criteria for adverse events ( CTCAE ). [update 2006 August 9; cited 20 Jul 2012]. Available from: http://ctep.cancer.gov/.

13. Keswara MA, Sudarsa IW, Golden N. The risk factor of neutropenia on locally advanced breast cancer patients treated with first cycle cyclophosphamide, doxorubicine, 5- Fluorouracil chemotherapy at Sanglah General Hospital Denpasar, Bali-Indonesia. Bali Med J. 2012 Sep;1(3):116-20.

14. Han Y, Yu Z, Wen S, Zhang B, Cao X, Wang X. Prognostic value of chemotherapy-induced neutropenia in earlystage breast cancer. Breast Cancer Res Treat. 2012 Oct;131(2):483-90.

15. Palappallil DS, Nair BL, Jayakumar KL, Puvathalil RT. Comparative study of the toxicity of 5-fluorouraciladriamycin-cyclophosphamide versus adriamycin- cyclophosphamide followed by paclitaxel in carcinoma breast. Indian J Cancer. 2011 Jan;48(1):68-73.

16. Balmukhanov TS, Khanseitova AK, Nigmatova VG, Ashirbekov EE, Talaeva SZ, Aitkhozhina NA. Polymorphisms at GSTM1, GSTP1, GSTT1 detoxification genes loci and risk of breast cancer in Kazakhstan population. Sci Res. 2013 Oct;2:114-8.

17. Huang MY, Wang YH, Chen FM, Lee SC, Fang WY, Cheng TL, et al. Multiple genetic polymorphisms of GSTP1 313AG, MDR1 3435CC, and MTHFR 677CC highly correlated with early relapse of breast cancer patients in Taiwan. Ann Surg Oncol. 2008 Jan;15(3):872-80.

18. de Aguiar ES, Giacomazzi J, Schmidt AV, Bock H, SaraivaPereira ML, Schuler-Faccini L, et al. GSTM1, GSTT1, and GSTP1 polymorphisms, breast cancer risk factors and mammographic density in women submitted to breast cancer screening. Rev Bras Epidemiol. 2012;15(2):246-55.

19. Vivenza D, Feola M, Garrone O, Monteverde M, Merlano M, Lo Nigro C. Role of the reninangiotensin-aldosterone system and the glutathione $\mathrm{S}$-transferase $\mathrm{Mu}, \mathrm{Pi}$ and Theta gene polymorphisms in cardiotoxicity after anthracycline chemotherapy for breast carcinoma. Int J Biol Markers. 2013 June;28(4):e336-47.

20. Ekhart C, Rodenhuis S, Smits PH, Beijnen JH, Huitema AD. An overview of the relations between polymorphisms in drug metabolising enzymes and drug transporters and survival after cancer drug treatment. Cancer Treat Rev. 2009 July;35(1):18-31. 